\title{
UNDERSTANDING VERTICAL GROUND DISPLACEMENT FROM P-SBAS USING GETIS-ORD GI* STATISTIC
}

\author{
INTERPRETANDO EL DESPLAZAMIENTO VERTICAL DEL SUELO DESDE P-SBAS UTILIZANDO LA \\ ESTADÍSTICA GI* DE GETIS-ORD
}

\author{
Ignacio Barberoa, ${ }^{a}$, Raúl Páez ${ }^{b}$, Cristina Torrecillas ${ }^{c}$ \\ a Escuela Técnica Superior de Ingeniería, Universidad de Sevilla, 41004 Sevilla, Spain. ignacio_barbero@us.es \\ b Departamento de Estadística e Investigación Operativa, Universidad de Cádiz,11510 Puerto Real, Spain. raul.paez@uca.es \\ c Departamento de Ingeniería Gráfica, Escuela Técnica Superior de Ingeniería, Universidad de Sevilla, 41004 Sevilla, Spain. \\ torrecillas@us.es
}

\begin{abstract}
:
The Differential Synthetic Aperture Radar Interferometric (DInSAR) algorithm has already shown its importance in volcanic monitoring. However, it is limited by atmospheric perturbations or temporal decorrelation, implying the existence of lowcoherence records that must be discarded. In vast studied areas, with thousands of points unevenly distributed, the interpretation of the results is usually complicated. This text presents an analysis of the vertical component variation on Tenerife island (Canary Islands), from 2005 to 2010, using Getis-Ord Gi* spatial statistic on ENVISAT DinSAR images. The ascending and descending images have been processed using the Parallel Small BAseline Subset (P-SBAS) algorithm, within ESA Grid Processing on Demand cloud environment. From Line of Sight results of both tracks, the vertical deformation speeds have been calculated over 72,207 points with high coherence $(>0.7)$. Finally, the $\mathrm{Gi}^{*}$ statistic has been applied, obtaining a map with statistical significance, where the high values of $\mathrm{Gi}^{\star}$, both positive and negative, imply the spatial clustering of likely ground movements. This map highlights areas with variable vertical kinematics on Tenerife Island, contributing to understanding of its geodynamics. The displacements obtained coincide with previous studies, even showing possible new relationships between some phenomena that should be considered. The $\mathrm{Gi}^{*}$ spatial statistic is an efficient and quick tool to extract information in a regional scale kinematic study.
\end{abstract}

Key words: subsidence, ENVISAT, DInSAR, spatial statistic, Tenerife

\section{Resumen:}

El algoritmo de Interferometría Diferencial con Radar de Apertura Sintética (DInSAR) ha mostrado su utilidad en la detección de cambios en la componente vertical en zonas vulcanológicas activas. Sin embargo, sus limitaciones en la obtención de datos, debido a perturbaciones atmosféricas o decorrelación temporal, implica la existencia de registros con poca coherencia que deben ser desechados. Cuando el área a estudiar tiene una extensión significativa, con miles de puntos distribuidos no homogéneamente por la zona, se complica la interpretación de los resultados. En este texto se presenta el análisis de la variación de la componente vertical de la isla de Tenerife (Canarias), desde 2005 a 2010 , empleando la estadística espacial $\mathrm{Gi}^{*}$ de Getis-Ord sobre los resultados obtenidos a partir del tratamiento de imágenes ENVISAT. Se han procesado las imágenes ascendentes y descendentes, usando el algoritmo Parallel Small BAseline Subset (P-SBAS), dentro del entorno de la ESA en la nube denominado Grid Processing on Demand. Desde los resultados en línea de vista de ambas trayectorias, se ha calculado las velocidades de deformación vertical para 72.207 puntos con alta coherencia $(>0.7)$. Finalmente, se ha aplicado la estadística espacial $\mathrm{Gi}^{*}$ de Getis-Ord a dichas velocidades, obteniendo un mapa con significación estadística, en el que los valores altos del estadístico $\mathrm{Gi}^{*}$, tanto positivos como negativos, implican la agrupación espacial de posibles movimientos del terreno. Este mapa destaca las áreas con cinemática vertical variable para toda la isla de Tenerife, ayudando a la comprensión de la geodinámica de la isla. Los desplazamientos obtenidos son coherentes con otros estudios, incluso muestran posibles relaciones entre algunos fenómenos que deberían ser tenidos en cuenta. Consideramos el uso del estadístico espacial $\mathrm{Gi}^{\star}$ una herramienta eficaz y rápida para extraer información en un estudio cinemático a escala regional.

Palabras clave: subsidencias, ENVISAT, DInSAR, estadística espacial, Tenerife

\section{Introduction}

Europe's COPERNICUS programme (ESA 2021a) provides global data from satellites as well as land, air and maritime measuring systems, spanning an extended period time. The image services are usually free to access and include information from SAR sensors, such as ENVISAT or Sentinel-1. Furthemore, developments relating DInSAR algorithms, such as the algorithm Parallel Small BAseline Subset (P-SBAS) (de Luca et al. 2015; Casu et al. 2014), enable the generation of surface deformations time series. This algorithm is one of the

‘Corresponding Author: Ignacio Barbero, ignacio_barbero@us.es 
SBAS techniques (Berardino et al. 2002) in the Grid Processing on Demand (G-POD) environment of ESA's Geohazards (ESA 2021b). G-POD accesses to ESA IT facilities, as well as its Earth Observation (EO) data files, and provides a friendly web user interface to process in cloud servers, instead of traditional desktop workstations. Some studies highlight the development of this tool to identify, monitor and evaluate risks related to geological processes (Galve et al. 2017).

The P-SBAS algorithm also permits generation of deformation time series in a very short time, taking advantage of distributed computing systems, by combining the available interferometric pairs. The results offer a high density of points with information to analyze, in locations where other terrestrial techniques have greater difficulty to collect observations p.e. due to the high cost of the GNSS network infrastructure and / or difficulty for physical accessing. These values are usually determined in the line of sight (LOS), not vertically, so the interferograms must be performed between passes in the same direction (ascending or descending). By comparing the matching values found amongst the results in both directions, it is possible to establish the vertical component in subsidence studies (Rosi et al. 2014).

Meanwhile, in vast study areas, such as the island of Tenerife (the Canary Islands) which covers over $2000 \mathrm{~km}^{2}$ (Fig. 1), the high spatial resolutions of the SAR data (ENVISAT $5 \times 25 \mathrm{~m}$ ), the improvement in the impact of atmospheric delays or the residual topographic values (Blanco-Sánchez et al. 2008), or the development of Persistent Scatterer Interferometry techniques (Crosetto et al. 2016), have increased the amount of highly coherence points available. Viewing the data available for the island at the same time can complicate the interpretation of results and the drawing of conclusions. This is particularly true if the phenomenon is regional and affect the entire island with small extensions. Given the speed with which it is possible to analyse large sets of vector points nowadays, it would be interesting to improve the detection of local anomalies in extensive areas, mapping those areas of interest irrespective of their size. The novelty of the proposed method is in the use of the graphic feature points instead raster data. These points are obtained directly from the image processing, avoiding resampling of data and its associated error. In this way, pattern identification techniques based on the clustering of geospatial data of statistical significance, are an interesting tool.

The Getis-Ord Gi* statistic is commonly used for hot/cold spot detection. It has already been used for space or space-time analysis in several recent studies within the field of Earth Sciences. Specifically, this has been used to improve the identification of tectonic structures and large landslides using geological data (Troiani et al. 2017); Páez et al. (2017) used it in the spatial-temporal analysis of user tracking for an active GNSS network by searching areas which were constantly used within a region, or on slope slides from SAR data (Lu et al. 2012; Teshebaeva et al. 2019; Lin et al. 2021). In this study case, its use is proposed on the elevation velocity values obtained from the LOS time series of P-SBAS processing. The application on these data can offer a map, with statistical significance, in which the high values of the $\mathrm{Gi}^{*}$ statistic, both positive and negative, imply the spatial grouping of anomalous vertical ground displacements.

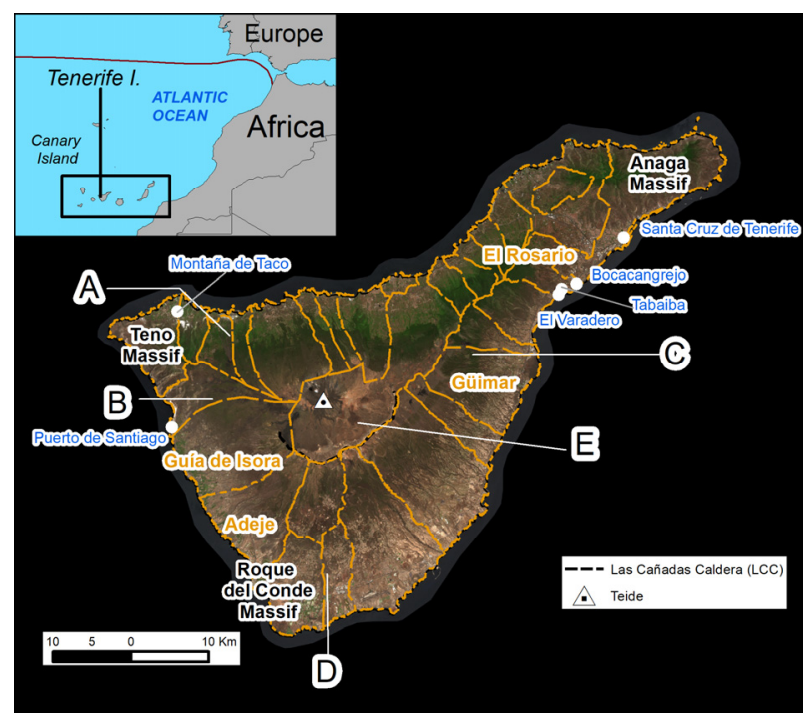

Figure 1: Municipalities (orange lines and text), some geological places and towns and, the subsidence zones studied in Tenerife: Garachico (A); Chío (B); East (C); South (D) and Las Cañadas Caldera (E). All figures in EPSG 25828.

This research presents a new DInSAR study on Tenerife. The choice of the island of Tenerife for a DinSAR study using this statistic is due to several reasons: 1) to the limited vegetation that due to its volcanic nature and altitude, offering a high level of coherence in DInSAR data; 2) to the presence of as many as four areas which are experiencing local subsidence detected in some studies both prior to and since Teide's volcanic reactivation in $2004 ; 3$ ) to no existence of the vertical velocity data derived from LOS of ascending and descending images published in any previous SAR study; and, 4) to the knowledge that the authors have about the geodynamics of the island from prior GNSS studies (Barbero et al. 2018; 2021). In this analysis, images from the ENVISAT satellite have been used between 2004 and 2010. This period covers a temporal space not presented in previous publications and closed to the detection of two new subsidence to the East and the South of Las Cañadas del Teide (LCC in Figure 1). The vertical velocities calculated using DInSAR will better evaluate the subsidence values than those offered in other studies and, finally, the application of the Getis-Ord $\mathrm{Gi}^{*}$ statistic on these data will highlight anomalous areas with statistical significance. It will improve the physical delimitation of these areas throughout the island. These areas may be compareble and added to those set out in the Vulnerable Elements Activity Map (VEAM) of Tenerife island, obtained from SENTINEL-1 images with only two years of time period (Solari et al. 2018).

\section{Background}

Tenerife is the largest island of a volcanic complex with seven islands called the Canary Islands. It is located in the Atlantic Ocean, close to the African passive continental margin (Fig. 1). The island has an active volcano named Teide, the world's third-highest volcanic structure with a height of $7,200 \mathrm{~m}$ from the seafloor, 3,718 $\mathrm{m}$ above sea level. The origin of the Canary Islands and its volcanism is still a matter of controversy with evidence for a mantle plume (Geldmacher et al. 2001; Mériaux et al. 2015), regional tectonics (Mezcua et al. 1992; 
Mantovani et al. 2007; Domínguez-Cerdeña et al. 2011) or a combination of both.

The unusual increase in seismic events in 2004, with some earthquakes $(M>3$, with depths between $0-17 \mathrm{~km})$ felt by the population (Almendros et al. 2007; Domínguez Cerdeña et al. 2018; Domínguez-Cerdeña, del Fresno, and Rivera 2011), increased the surface deformation studies on the island using SAR data. The first studies were carried out between 1992 and 2000 from 18 SAR images (Fernández et al. 2003) (see Table 1) and revealed two subsiding areas, Garachico (A in Figure 1) measuring with $10 \mathrm{~cm}$ and an extension of $15 \mathrm{Km} 2$ and Chío ( $B$ in Figure 1) with $3 \mathrm{~cm}$ and $8 \mathrm{Km} 2$ in the northwest area of the island. These height variations were partially attributed to a decrease of the groundwater level due to water extraction, in times of scarcity, from some of 1052 horizontal underground galleries confirmed in Tenerife. The Garachico deformation has evolved more steadily, by approximately $10 \mathrm{~mm} / \mathrm{yr}$ since 1992. The Chío deformation was almost the same size in 1992-1998 as in 1998-2000, and it seems to have increased more in the latter period (Custodio et al. 2016; Fernández et al. 2005). Using data collected between 1992 and 2005, a period which included the 2004 unrest, a DInSAR study with 55 descending images between 1992 and 2005 detected, besides the two-known subsidence, two new ones to the East (C in Figure 1) and South of LCC (D in Figure 1). Part of this deformation can be attributed to drops in water table interacting with existing faults. Finally, this study detected a broad subsidence pattern with maximum ground velocities of about $4 \mathrm{~mm} / \mathrm{year}$ related to gravitational sinking of the dense core of the island into a weak lithosphere (Fernández et al. 2009). In following studies, Chío subsidence is usually detected and on lesser occasions the rest. A summary of those researches are presented in Table 1.

\section{Input data}

The satellite for the ENVISAT mission features C-band sensors with a wavelength of $5.6 \mathrm{~cm}$, review period of 35 days, angle of incidence of $23^{\circ}$ and a nominal pixel resolution of $5 \mathrm{~m} \times 25 \mathrm{~m}$. The data used from the ENVISAT satellite cover two different tracks for the studied area: 388 ascending and the 352 descending. The details of ENVISAT data used in this work are summarized in Table 2.

The result of the calculation of the vertical velocity $(\mathrm{Vv})$, following Rosi et al. (2014) methodology, was 72,204 coincident points between 153,268 ascending points and 154,985 descending. The method also gives us the possibility of ruling out areas affected by sliding from the main direction of deformation, which are not the target and are considered as noise in the analysis. To achieve this, the points whose angular value of the main direction of deformation is between $\geq 45^{\circ}$ and $\leq-45^{\circ}$ were filtered. These angles have been obtained from the trigonometric relationships for the vertical velocity components and the projected in the East direction. Finally, the final set or data input consisted of 55,225 points with $V v$ velocity spread throughout the island (Fig. 2).

Table 1: Previous DInSAR studies in Tenerife.

\begin{tabular}{|c|c|c|}
\hline Years/Platform & Methodology and Data & Analysis (Reference) \\
\hline 1992-2000/ERS-1, ERS-2 & $\begin{array}{l}\text { LOS + GNSS (Fringe) } \\
18 \text { descending images } \\
21 \text { interferograms }\end{array}$ & $\begin{array}{l}\text { No deformation in LCC (E in Figure 1). } \\
\text { Garachico subsidence: } 5-10 \mathrm{~cm} \text {, increasing. } \\
\text { Chío subsidence: } 3-5 \mathrm{~cm} \text {, increasing. } \\
\text { (Fernández et al. } 2003 \text {; Fernández et al. } 2005\end{array}$ \\
\hline 1992-2005/ERS-1, ERS-2 & $\begin{array}{c}\text { LOS (SBAS) } \\
55 \text { descending images } \\
182 \text { interferograms }\end{array}$ & $\begin{array}{c}\text { No deformation in LCC. } \\
\text { Detected Chío and Garachico subsidence. } \\
\text { Two new subsidence in East }(8 \mathrm{~cm}) \text { and South }(6 \mathrm{~cm}) \\
\text { A broad subsidence pattern about } 4 \mathrm{mmyr}^{-1} \\
\text { (Fernández et al. 2009) }\end{array}$ \\
\hline 2003-2006/ENVISAT & $\begin{array}{l}\text { LOS (Terrain correction) } \\
\begin{array}{c}13 \text { ascending images } \\
4 \text { interferograms } \\
16 \text { descending images } \\
1 \text { interferogram }\end{array}\end{array}$ & $\begin{array}{l}\text { No deformation in LCC. } \\
\text { No clear subsidence from DInSAR data } \\
\text { (Samsonov et al. 2008) }\end{array}$ \\
\hline 2003-2008/ENVISAT & $\begin{array}{c}\text { LOS (Coherent pixel) } \\
19 \text { ascending images (5 years) } \\
25 \text { descending images (4 years) }\end{array}$ & $\begin{array}{c}\text { Garachico: } 2-8 \mathrm{~cm} \text { (asc) and } 4 \mathrm{~cm} \text { (des) } \\
\text { Chio: } 4 \mathrm{~cm} \text { (both) } \\
\text { (Arjona et al. 2010) }\end{array}$ \\
\hline 2015-2018/SENTINEL-1 & $\begin{array}{c}\text { LOS + GNSS (PSI) } \\
40 \text { ascending images } \\
135 \text { descending images }\end{array}$ & $\begin{array}{l}\text { Four subsidence: } 5 \mathrm{mmyr}^{-1} \\
\text { Central area: } 5 \mathrm{mmyr}^{-1} \\
\text { (Dias et al. 2018) }\end{array}$ \\
\hline 2014-2016/SENTINEL & $\begin{array}{c}\text { LOS (PSI) } \\
51 \text { descending images }\end{array}$ & $\begin{array}{l}218 \text { ADAs with threshold } \pm 4 \text { mmyr }^{-1} \\
\text { (Solari et al. 2018) }\end{array}$ \\
\hline
\end{tabular}


Table 2: ENVISAT image used.

\begin{tabular}{c|c|c|c|c} 
Start & Stop & Track & Pass & $\begin{array}{c}N^{\circ} \\
\text { images }\end{array}$ \\
\hline $11 / 06 / 2004$ & $08 / 10 / 2010$ & 352 & Descending & 34 \\
$13 / 02 / 2005$ & $03 / 05 / 2009$ & 388 & Ascending & 33
\end{tabular}

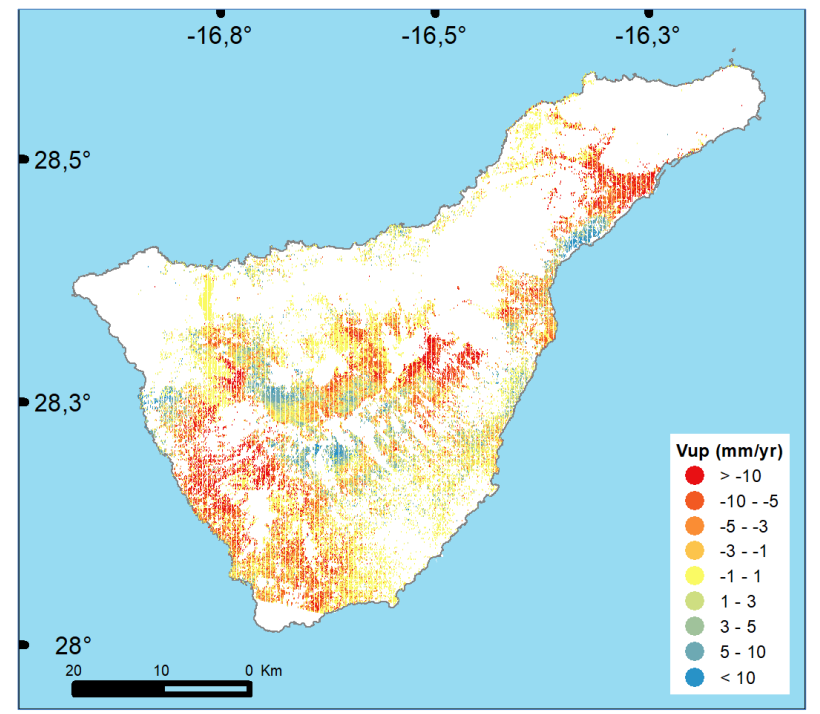

Figure 2: 2004-2010 Vertical kinematic of Tenerife Island.

\section{Methodology}

The Getis-Ord $G_{i}^{*}$ statistic is a local-level spatial autocorrelation index where spatial dependence is assumed (Anselin and Rey 2010; Ord and Getis 1995), something that is previously established using Moran's I global statistic (Anselin 1995). A $G_{i}^{*}$ statistic is calculated for each point $i$ from the cluster of observations closer than a threshold $d$ from $i$, where $i$ is identified with a geographical location. This can be formally expressed with a binary weight matrix $\mathrm{W}(d)$, where matrix elements are $w_{i j}(d)=1$ if the distance from $i$ to $j$ is less than $d$, and $w_{i j}(d)=0$ in other case. Thus, we define the Getis-Ord $G_{i}^{*}$ local statistic reference to $d$ as Eq. (1):

$G_{i}^{*}(d)=\frac{\sum_{j=1}^{n} w_{i j}(d) x_{j}}{\sum_{j=1}^{n} x_{j}}$

where may equal $i$ )

$$
x_{j}=\text { attribute vertical velocity } V v \text { at location } j(j
$$

$$
n=\text { total number of points with } V_{v} \text { calculated }
$$

The distribution of the $G_{i}^{*}(d)$ statistic is normal when the normality is also observed in the underlying distribution of variable $X$. However, when the underlying distribution is nonnormal, the statistic test becomes nonnormal correspondingly. Increasing the number of spatial points in the clusters analyzed will help the distribution of the $G_{i}^{*}$ statistic approach normality (Caldas de Castro and Singer 2006; Songchitruksa and Zeng 2010). The most common method is to raise the value of $d$ to include more $x_{j}$ Under the exact or asymptotical normal conditions, $G_{i}^{*}(d)$ is usually standardized, obtaining the standard normal variates, Eq. (2):

$$
Z\left(G_{i}^{*}(d)\right)=\frac{\sum_{j=1}^{n} w_{i j}(d) x_{j}-\bar{x} \sum_{j=1}^{n} w_{i j}^{2}(d)}{s \sqrt{\frac{n \sum_{j=1}^{n} w_{i j}^{2}(d)-\left(\sum_{j=1}^{n} w_{i j}\right)^{2}}{n-1}}}
$$

This is essentially a $Z$ score and therefore can be expressed as statistical significance. Therefore, significant negative $Z$ reveals spatial clustering of low values of $V v$ within distance $d$, while significant positive $Z$ are indicative of spatial clustering of high values of $V v$ within distance $d$.

To calculate the threshold of the parameter $d$, the spatial correlogram has been applied to the analysis phenomenon, which is an alternative measure of global spatial autocorrelation that is not based on the specification of a spatial weighting matrix. Instead, a local regression fits the covariances or correlations calculated for all pairs of observations as a function of the distance between them (Bjørnstad and Falck 2001).

\section{Results and discussion}

The Getis-Ord $G_{i}^{*}$ statistic results offer a clustering and significance map based on a weight matrix. Considering subsidence areas with high significance values with respect to their surroundings, see Figure 3 . This statistic clearly identifies and limits the subsidence of Chío (to the east of this town, in the North of municipality of Guía de Isora, see B in Figure 1). Furthermore, the subsidence to the east of LCC (C in Figure 1) is identified but composed of two areas: that of the Fernández et al. (2009) and a new one at the east of this main one (in the municipality of Guimar).

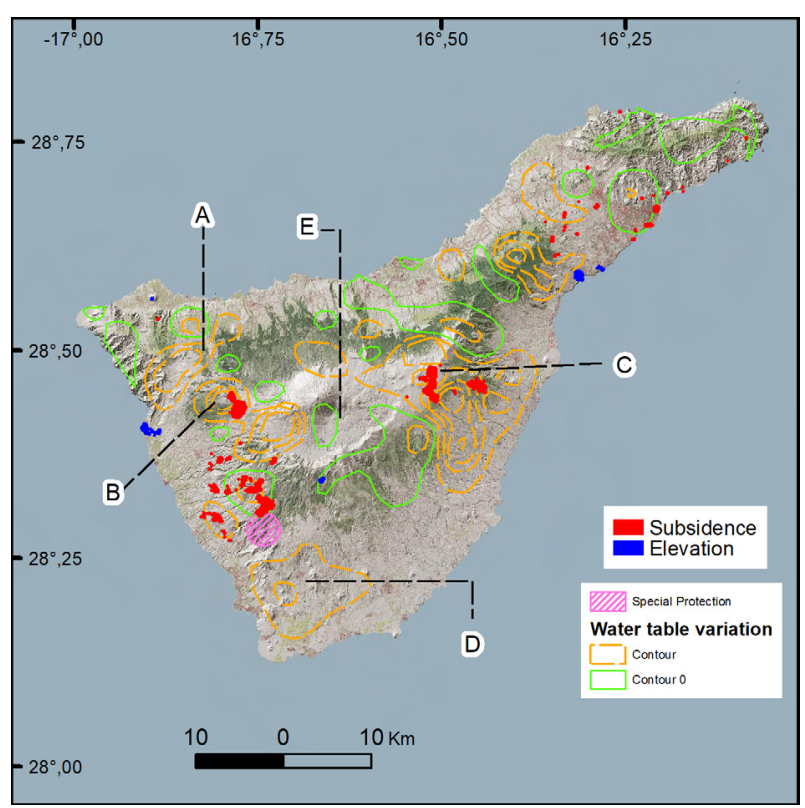

Figure 3: High significance area of $\mathrm{Gi}^{*}$ statistic (red and blue areas) and variation of the water table level 1985-2000 with isolines every $20 \mathrm{~m}$ (CIATF 2021)

This study visualizes new dynamics to consider. Firstly, about subsidence, several subsidence blocks to the south of Chío and calculated with equal significance as Chío (the municipality of Guía de Isora and Adeje). In addition, this is the first time that it is worth commenting on some data in the Anaga massif (municipality El Rosario), defined as several small areas, perhaps due to the lack of 
coherence density. There are other small subsidence areas in this massif in the city of Santa Cruz de Tenerife and its surroundings, in urban areas. All these areas are linked to zones where the water table had decreased in the period 1985-2000 (Fig. 3). It is unknown whether this level has dropped over the following years.

Secondly, two elevations are identified in urban areas: north-eastern coast (villages of El Varadero, Tabaiba and Bocacangrejo, inside of El Rosario municipality), and to the west of the island (villages of Puerto de Santiago and Montaña de Taco), see Figures 1 and 3 . There is only one elevation in a non-urban area, on the outer south edge of the LCC and located in a stream of lava. Finally, nothing relevant is detected within the LCC, in Garachico (A in Figure 1) or in the south of the island (D in Figure 1), due to the significance of the $G_{i}^{*}$ statistic is lower (D and $\mathrm{E}$ ) or the number of input data is poor $(A)$.

\section{Conclusions}

This study provides vertical velocities for the island of Tenerife, derived from ascending and descending paths of the ENVISAT satellite, using the P-SBAS multitemporal interferometric methodology as a baseline between 2004 and 2010. The DInSAR vertical velocity map offers heterogeneous results and a lack of data for the entire island (Fig. 2). The Getis-Ord Gi* statistic was applied to the calculated vertical velocities, obtaining a map which represents the clustering of points with similar absolute vertical velocities. Filtering by those of high statistical significance, the procedure used made it possible to identify and delimit anomalous subsidence and elevation phenomena on both a regional and local scale.

Furthermore, a temporary space not previously studied has been covered starting at the beginning of the detection of new subsidence areas to the east and south of LCC (Fernández et al. 2009). Although subsequent studies did not detect them (Samsonov et al. 2008; Arjona et al. 2010), Sentinel-1 derived data had re-tagged them with velocities greater than $4 \mathrm{~mm} / \mathrm{yr}$ (Solari et al. 2018; Dias, Catalao, and Marques 2018).

The subsidence results were linked to the effects of settlement due to local drops in the water table, resulting in subsidence in the areas with the most significant decreases, of as much as $40 \mathrm{~m}$ or $60 \mathrm{~m}$ over a fifteen-year period according to the CIATF map (Fig. 3). It was not possible to correctly delimit the subsidence in Garachico using geostatistics, but in this case, it was due to a lack of points in the surrounding area during both passes. Also, new dynamics have been detected that should be monitored now that Sentinel-1 has already enough temporality for it and confirm or not their evolutions.

Finally, note the lack input data in the northern part of the island, coinciding with dense vegetation areas. These afeas offer low phase coherence, a basic requirement when processing SAR images multitemporal, and requires completing these studies with other groundbased methodologies (GNSS or classical geodesy) to cover the whole island.

\section{References}

ALMENDROS, J., IBÁÑEZ, J. M., CARMONA, E., and ZANDOMENEGHI, D., 2007. Array analyses of volcanic earthquakes and tremor recorded at Las Cañadas caldera (Tenerife Island, Spain) during the 2004 seismic activation of Teide volcano. Journal of Volcanology and Geothermal Research, 160(3-4), pp. 285-299. DOI: 10.1016/j.jvolgeores.2006.10.002

ANSELIN, L., 1995. Local Indicators of Spatial Association-LISA. Geographical Analysis, 27(2), pp. 93-115. DOI: 10.1111/j.1538-4632.1995.tb00338.x

ANSELIN, L., and REY. S.J., 2010. Perspectives on Spatial Data Analysis. In Advances in Spatial Science, 61, pp. 1-20. DOI: $10.1007 / 978-3-642-01976-0 \_1$

ARJONA, A., MONELLS, D., FERNÁNDEZ, J., DUQUE, S., and MALLORQUI, J., 2009. Deformation analysis employing the Coherent Pixel Technique and ENVISAT and ERS images in Canary Islands. In Proc. of 'Fringe.

BARBERO, I., TORRECILlAS, C., PÁEZ, R., PRATES, G., and BERROCOSO, M., 2021. Recent Macaronesian kinematics from GNSS ground displacement analysis. Studia Geophysica et Geodaetica, 65(1), pp. 15-35. DOI: $10.1007 / \mathrm{s} 11200-020-1122-x$

BARBERo, I., TORRECILLAS, C., PRATES, G., PÁEZ, R., GARATE, J., GARCíA, A., and BERROCOSO, M., 2018. Assessment of ground deformation following Tenerife's 2004 volcanic unrest (Canary Islands). Journal of Geodynamics, 121, pp. 1-8. DOI: 10.1016/j.jog.2018.06.002

BERARDINO, P., FORNARO, G., LANARI, R., and SANSOSTI, E., 2002. A new algorithm for surface deformation monitoring based on small baseline differential SAR interferograms. IEEE Transactions on geoscience and remote sensing, 40(11), pp. 2375-2383. DOI: 10.1109/TGRS.2002.803792

BJØRNSTAD, O. N., and FALCK, W., 2001. Nonparametric spatial covariance functions: estimation and testing. Environmental and Ecological Statistics, 8(1), pp. 53-70. DOI: 10.1023/A:1009601932481

BLANCO-SANCHEZ, P., MALLORQUÍ, J. J., DUQUE, S., and MONELLS, D., 2008. The coherent pixels technique (CPT): An advanced DInSAR technique for nonlinear deformation monitoring. In Earth sciences and mathematics (pp. 11671193). Birkhäuser Basel. DOI: 10.1007/s00024-008-0352-6

CALDAS DE CASTRO, M., and SINGER, B. H., 2006. Controlling the false discovery rate: a new application to account for multiple and dependent tests in local statistics of spatial association. Geographical Analysis, 38(2), pp. $180-208$. DOI: $10.1111 / j .0016-7363.2006 .00682 . x$ 
CASU, F., ELEFANTE, S., IMPERATORE, P., ZINNO, I., MANUNTA, M., DE LUCA, C., and LANARI, R., 2014. SBASDInSAR parallel processing for deformation time-series computation.IEEE Journal of Selected Topics in Applied Earth Observations and Remote Sensing, 7(8), pp. 3285-3296. DOI: 10.1109/JSTARS.2014.2322671

CIATF. 2021. Consejo Insular de Aguas de Tenerife. Plan Hidrológico Insular de Tenerife (aguastenerife.org). Available: https://www.aguastenerife.org/images/pdf/documentacion_grafica/plano16.pdf [7/15, 2021].

CROSETTO, M., MONSERRAT, O., CUEVAS-GONZÁLEZ, M., DEVANTHÉRY, N., and CRIPPA, B., 2016. Persistent scatterer interferometry: A review. ISPRS Journal of Photogrammetry and Remote Sensing, 115, pp. 78-89. DOI: 10.1016/j.isprsjprs.2015.10.011

CUSTODIO, E., DEL CARMEN CABRERA, M., PONCELA, R., PUGA, L. O., SKUPIEN, E., and DEL VILLAR, A., 2016. Groundwater intensive exploitation and mining in Gran Canaria and Tenerife, Canary Islands, Spain: Hydrogeological, environmental, economic and social aspects. Science of the Total Environment, 557, pp. 425-437. DOI: 10.1016/j.scitotenv.2016.03.038

DE LUCA, C., CUCCU, R., ELEFANTE, S., ZINNO, I., MANUNTA, M., CASOLA, V., and CASU, F., 2015. An on-demand web tool for the unsupervised retrieval of earth's surface deformation from SAR data: The P-SBAS service within the ESA G-POD environment. Remote Sensing, 7(11), 15630-15650. DOI: 10.3390/rs71115630

DIAS, P., CATALAO, J., and MARQUES, F. O., 2018. Sentinel-1 InSAR data applied to surface deformation in Macaronesia (Canaries and Cape Verde). Procedia computer science, 138, pp. 382-387. DOI: 10.1016/j.procs.2018.10.054.

DOMÍNGUEZ-CERDEÑA, I., DEL FRESNO, C., and RIVERA, L., 2011. New insight on the increasing seismicity during Tenerife's 2004 volcanic reactivation. Journal of Volcanology and Geothermal Research, 206(1-2), pp. 15-29. DOI: 10.1016/j.jvolgeores.2011.06.005

DOMíNGUEZ CERDEÑA, I. D., DEL FRESNO, C., CANTAVELLA, J. V., FELPETO, A., LOZANO, L., MEDINA, L. C., and LÓPEZ, C., 2018. Comment on "Geochemical evidences of seismo-volcanic unrests at the NW rift-zone of Tenerife, Canary Islands, inferred from diffuse CO 2 emission” by Hernández PA, Padilla G., Barrancos J., Melián G., Padrón E., Asensio-Ramos M., Rodríguez F., Pérez NM, Alonso M., and Calvo D. [Bull Volcanol (2017) 79: 30]. Bulletin of Volcanology, 80(1), pp. 1-4. DOI: 10.1007/s00445-017-1182-0

ESA. 2021a. “European COPERNICUS Program.” 2021. Available: https://www.copernicus.eu/es [7/15, 2021].

ESA. 2021b. "European Space Agency Grid Processing on Demand." 2021. Available: https://gpod.eo.esa.int/ [7/15, 2021].

FERNÁNDEZ, J., TIZZANI, P., MANZO, M., BORGIA, A., GONZÁLEZ, P. J., MARTÍ, J., and LANARI, R., 2009. Gravitydriven deformation of Tenerife measured by InSAR time series analysis. Geophysical Research Letters, 36(4). DOI: 10.1029/2008GL036920

FERNÁNDEZ, J., YU, T. T., RODRIGUEZ-VELASCO, G., GONZÁLEZ-MATESANZ, J., ROMERO, R., RODRIGUEZ, G., and BLANCO, M. J., 2003. New geodetic monitoring system in the volcanic island of Tenerife, Canaries, Spain. Combination of InSAR and GPS techniques. Journal of volcanology and geothermal research, 124(3-4), pp. $241-253$. DOI: 10.1016/S0377-0273(03)00073-8

FERNÁNDEZ, J., ROMERO, R., CARRASCO, D., TIAMPO, K. F., RODRÍGUEZ-VELASCO, G., APARICIO, A., and GONZÁLEZ-MATESANZ, F. J., 2005. Detection of displacements on Tenerife Island, Canaries, using radar interferometry. Geophysical Journal International, 160(1), pp. 33-45. DOI: 10.1111/j.1365-246X.2005.02487.X

GALVE, J. P., PÉREZ-PEÑA, J. V., AZAÑÓN, J. M., CLOSSON, D., CALÓ, F., REYES-CARMONA, C., and BALLY, P., 2017. Evaluation of the SBAS InSAR service of the European space Agency's Geohazard Exploitation Platform (GEP). Remote Sensing, 9(12), 1291. DOI: 10.3390/rs9121291

GELDMACHER, J., HOERNLE, K., VAN DEN BOGAARD, P., ZANKL, G., and GARBE-SCHÖNBERG, D., 2001. Earlier history of the $\geq 70$-Ma-old Canary hotspot based on the temporal and geochemical evolution of the Selvagen Archipelago and neighboring seamounts in the eastern North Atlantic. Journal of volcanology and geothermal research, 111(1-4), pp. 55-87. DOI: 10.1016/S0377-0273(01)00220-7

LIN, S. Y., LIN, C. W., and VAN GASSELT, S., 2021. Processing Framework for Landslide Detection Based on Synthetic Aperture Radar (SAR) Intensity-Image Analysis. Remote Sensing, 13(4), 644. DOI: 10.3390/rs13040644.

LU, P., CASAGLI, N., CATANI, F., and TOFANI, V., 2012. Persistent Scatterers Interferometry Hotspot and Cluster Analysis (PSI-HCA) for detection of extremely slow-moving landslides. International journal of remote sensing, 33(2), pp. 466-489. DOI: 10.1080/01431161.2010.536185

MANTOVANI, E., VITI, M., BABBUCCI, D., and ALBARELLO, D., 2007. Nubia-Eurasia kinematics: an alternative interpretation from Mediterranean and North Atlantic evidence. Annals of Geophysics, 50(3). DOI: 10.4401/ag-3073

MÉRIAUX, C. A., DUARTE, J. C., DUARTE, S. S., SCHELLART, W. P., CHEN, Z., ROSAS, F., and TERRINHA, P., 2015. Capture of the Canary mantle plume material by the Gibraltar arc mantle wedge during slab rollback. Geophysical Journal International, 201(3), pp. 1717-1721. DOI: 10.1093/gji/ggv120 
MEZCUA, J., BUFORN, E., UDÍAS, A., and RUEDA, J., 1992. Seismotectonics of the Canary islands. Tectonophysics, 208(4), pp. 447-452. DOI: 10.1016/0040-1951(92)90440-H

ORD, J. K., and GETIS, A., 1995. Local spatial autocorrelation statistics: distributional issues and an application. Geographical analysis, 27(4), pp. 286-306. DOI: 10.1111/j.1538-4632.1995.tb00912.x

PÁEZ, R., TORRECILLAS, C., BARBERO, I., and BERROCOSO, M., 2017. Regional positioning services as economic and construction activity indicators: the case study of Andalusian Positioning Network (Southern Spain). Geocarto international, 32(1), pp. 44-58. DOI: 10.1080/10106049.2015.1120358

ROSI, A., AGOSTINI, A., TOFANI, V., and CASAGLI, N., 2014. A procedure to map subsidence at the regional scale using the persistent scatterer interferometry (PSI) technique. Remote Sensing, 6(11), pp. 10510-10522. DOI: $10.3390 /$ rs61110510

SAMSONOV, S., TIAMPO, K., GONZÁlEZ, P. J., PRIETO, J., CAMACHO, A. G., and FERNÁNDEZ, J., 2008. Surface deformation studies of Tenerife Island, Spain from joint GPS-DInSAR observations. In 2008 Second Workshop on Use of Remote Sensing Techniques for Monitoring Volcanoes and Seismogenic Areas (pp. 1-6). IEEE. DOI: 10.1109/USEREST.2008.4740337

SOLARI, L., BARRA, A., HERRERA, G., BIANCHINI, S., MONSERRAT, O., BÉJAR-PIZARRO, M., and MORETTI, S., 2018. Fast detection of ground motions on vulnerable elements using Sentinel-1 InSAR data. Geomatics, Natural Hazards and Risk, 9(1), pp. 152-174. DOI: 10.1080/19475705.2017.1413013

SONGCHITRUKSA, P., and ZENG, X., 2010. Getis-Ord spatial statistics to identify hot spots by using incident management data. Transportation research record, 2165(1), pp. 42-51. DOI: 10.3141/2165-05

TESHEBAEVA, K., ECHTLER, H., BOOKHAGEN, B., and STRECKER, M., 2019. Deep-seated gravitational slope deformation (DSGSD) and slow-moving landslides in the southern Tien Shan Mountains: new insights from InSAR, tectonic and geomorphic analysis. Earth surface processes and landforms, 44(12), pp. 2333-2348. DOI: 10.1002/esp.4648

TROIANI, F., PIACENTINI, D., DELLA SETA, M., and GALVE, J. P., 2017. Stream Length-gradient Hotspot and Cluster Analysis (SL-HCA) to fine-tune the detection and interpretation of knickzones on longitudinal profiles. Catena, 156, pp. 30-41. DOI: 10.1016/j.catena.2017.03.015 